\title{
Cooperative Models in International
}

Relations Research 


\section{Cooperative Models in International Relations Research}

\section{Edited by}

Michael D. Intriligator

University of California, Los Angeles

and

Urs Luterbacher

The Graduate School of International Studies, Geneva

Springer Science+Business Media, LLC 


\section{Library of Congress Cataloging-in-Publication Data}

Cooperative models in international relations research / edited by Michael D. Intriligator and Urs Luterbacher.

$$
\text { p. } \mathrm{cm} \text {. }
$$

Includes bibliographical references.

ISBN 978-1-4613-6206-7 ISBN 978-1-4615-2790-9 (eBook)

DOI 10.1007/978-1-4615-2790-9

1. International relations - Research. I. Intriligator, Michael

D. II. Luterbacher, Urs.

JX1291.C628 1993

$327.072-$ dc20

93-5936

Copyright (C) 1994 bySpringer Science+Business Media New York Originally published by Kluwer Academic Publishers in 1994 Softcover reprint of the hardcover 1st edition 1994

All right reserved. No part of this publication may be reproduced, stored in a retrieval system or transmitted in any form or by any means, mechanical, photo-copying, recording, or otherwise, without the prior written permission of the publisher, Springer Science+Business Media, LLC.

Printed on acid-free paper 


\section{Contents}

Contributing Authors vii

Introduction Cooperative Models in International Relations Research

Michael D. Intriligator and Urs Luterbacher

I Game Theory and Cooperation: General Aspects

7

1

Sources in Game Theory for International Relations Specialists

9

Barry O'Neill

2

On Coalition Games

Martin Shubik

3

From Conflict to Cooperation in the Study of International Security Michael D. Intriligator

4

A Theory of Cooperation in the Triad

Urs Luterbacher

II Game Theory and Cooperation: Specific Applications

5

International Cooperation Among Relative-Gains Maximizers

Duncan Snidal

6

The Problem of Absolute and Relative Gains in International Relations Theory

Robert Powell 
7

Implementation Through Sequential Unanimity Games Jerry R. Green and Jean-Jacques Laffont

III Deterrence

8

Rational Deterrence in an Imperfect World

Barry Nalebuff

\section{9}

A Question of Procedure at the Vienna Arms Talks Barry O'Neill

IV Escalation and Crises

Limited Nuclear Options and the Dynamics of Escalation

Robert Powell

11

Signaling Difficulties with Linkage in Crisis Bargaining James D. Morrow

12

Are Crises Rational? A Game-Theoretic Analysis

Steven J. Brams and D. Marc Kilgour

13

The Origin of Games: A Theory of the Formation of Ordinal Preferences and Games

Vinod K. Aggarwal and Pierre Allan

14

An Economic Analysis of Cooperation in the European Community

$S$. Weber and H. Wiesmeth

15

Labor Relations in International Comparison, or Why Humans (and Nations) Sometimes Cooperate and Sometimes Don't

Jean-Christian Lambelet

Index 


\title{
Contributing Authors
}

\author{
Vinod K. Aggarwal \\ Department of Political Science \\ University of California \\ Berkeley \\ Pierre Allan \\ Department of Political Science \\ University of Geneva \\ Steven J. Brams \\ Department of Political Science \\ New York University \\ Jerry R. Green \\ Department of Economics \\ Harvard University \\ Michael D. Intriligator \\ Departments of Economics \& Political \\ Science \\ University of California \\ Los Angeles \\ D. Marc Kilgour \\ Department of Mathematics \\ Wilfrid Laurier University \\ Jean-Jacques Laffont \\ Department of Economics \\ University of Toulouse
}

Jean-Christian Lambelet

Department of Economics \& Political Economics

University of Lausanne

Urs Luterbacher

Department of Political Science

The Graduate School of International Studies

Geneva

James D. Morrow

Hoover Institution

Stanford University

Barry Nalebuff

School of Organization and

Management and Department of

Political Science

Yale University

\section{Barry O'Neill}

School of Organization \& Management Yale University

\section{Robert Powell}

Department of Political Science

University of California

Berkeley 
Martin Shubik

Cowles Foundation for Research in Economics

Yale University

\section{Duncan Snidal}

The Irving B. Harris Graduate School of Public Policy Studies

University of Chicago

\section{Shlomo Weber}

Department of Economics

Southern Methodist University

\section{H. Wiesmeth}

Department of Economics

Technical University of Dresden 


\section{Cooperative Models in International}

Relations Research 